\title{
Prey selection by an obligate coral-feeding wrasse and its response to small-scale disturbance
}

\author{
J. L. McIlwain ${ }^{1,2, *}$, G. P. Jones ${ }^{1}$ \\ ${ }^{1}$ Department of Marine Biology, James Cook University, Townsville 4811, Queensland, Australia \\ ${ }^{2}$ Australian Institute of Marine Science, PO Box 264, Dampier 6713, Western Australia, Australia
}

\begin{abstract}
Coral reefs are subject to both natural and anthropogenic disturbances that may have detrimental effects on resident fish populations. This study examined the association between the coral-feeding wrasse Labrichthys unilineatus and the coral it feeds on, and investigated how the fish species responds to disturbance. Fish abundance was positively correlated with percentage scleractinian coral cover at 3 different scales of sampling $\left(4,100\right.$ and $250 \mathrm{~m}^{2}$ sampling units). Juveniles and, to a lesser extent, mature females were closely associated with patches of Acropora nobilis and A. elseyi, the cover of these corals being much greater inside fish home ranges. The habitat of the larger, wider ranging males reflected the cover of corals within the study area which was dominated by Montipora spp. and $A$. hyacinthus. Ontogenetic changes in diet reflected both changes in the availability of different coral species and changes in feeding selectivity. Juveniles had a narrower range of coral types available, but were more selective than larger fish, preferentially consuming many species of low abundance. At the other extreme, adult males fed almost exclusively on the common acroporid species in proportions reflecting their availability. Strong ontogenetic patterns in selectivity also extended to the relative consumption of undamaged and damaged tissues of coral colonies, the latter including bleached, diseased and broken edges of live corals. Damaged tissue of coral colonies was an important component of the diet of adult $L$. unilineatus, particularly males, which consumed more damaged than undamaged tissue, despite its low availability. Results of an electivity index showed that all coral colonies (in the feeding territories) that presented damaged tissue were strongly selected and none were avoided. Experimental physical disturbance to coral patches on a scale of $1 \mathrm{~m}^{2}$ quadrats resulted in a dramatic increase in the number of bites taken by $L$. unilineatus, compared with control plots. The increase was short term, with feeding intensity returning to the pre-disturbance level within $24 \mathrm{~h}$ of the time of initial damage. Individual feeding rates were also enhanced by the disturbance event, with fish in the vicinity of disturbed plots exhibiting a $50 \%$ increase in feeding rate. The reason for selection of damaged corals is unknown but a loss of nematocysts or release of mucous or chemical attractants may be involved.
\end{abstract}

KEY WORDS: Corallivores · Disturbance $\cdot$ Coral reef fish $\cdot$ Labrids $\cdot$ Coral disease

\section{INTRODUCTION}

Coral reefs represent unstable habitats for the diverse fish assemblages that they support. Natural disturbances such as cyclones, crown-of-thorns outbreaks and sea urchin die-offs can produce massive short-term changes to the physical and biological

\footnotetext{
"Present address: Department of Zoology, University of Western Australia, Nedlands, Perth 6907. Western Australia, Australia. E-mail: mcilwain@cyllene.uwa.edu.au
}

nature of the substratum (e.g. Connell 1978, Woodley et al. 1981, Harmelin-Vivien \& Laboute 1986, Hughes et al. 1987, Jackson 1991). These disturbances punctuate longer-term, but irregular, periods of coral recovery, resulting in a dynamic substratum (Pearson 1981, Jackson 1991). Fish communities associated with coral reefs generally exhibit spatial changes that are associated with measurable features of the habitat such as coral cover (Carpenter et al. 1981, Bell \& Galzin 1984, Bell et al. 1985, Bouchon-Navaro \& Bouchon 1989, Jones \& Kaly 1995) and topographic complexity (Glad- 
felter \& Gladfelter 1978, Luckhurst \& Luckhurst 1978, Roberts \& Ormond 1987). The documented responses of fish communities to disturbances affecting these variables vary among species and locations studied, with some authors finding substantial effects (Kaufman 1983, Lassig 1983, Sano et al. 1984, 1987, Williams 1984, Bouchon-Navaro et al. 1985, Pfeffer \& Tribble 1985 ) and others emphasizing the resilience to disturbance (Walsh 1983, Wellington \& Victor 1985, Williams 1986, Guzman \& Robertson 1989).

The fish species most likely to be affected by disturbance are obligate coral-dwelling or feeding species, whose distribution and abundance are closely linked to coral cover (Bell \& Galzin 1984, Bell et al. 1985, Bouchon-Navaro \& Bouchon 1989, but see Fowler 1990, Cox 1994). It has been suggested that these species are excellent indicators of the health of coral reefs (Reese 1977, Hourigan et al. 1988). There is increasing evidence that fish communities respond to humaninduced changes in habitat structure (e.g. Dawson Shepherd et al. 1992, Jones \& Kaly 1995). Obligate corallivores and coral dependents may be eliminated from areas subject to complete coral devastation and may be slow to recover (Sano et al. 1984, 1987, Williams 1985). This group includes numerous damselfishes (Pomacentridae), gobies (Gobiidae) and butterflyfish (Chaetodontidae), which are among the most speciose families of coral reef fishes. It also includes Labrichthys unilineatus (Guichenot, 1847), which is unusual among wrasses as one of a few species which are specialised coral polyp feeders (Sano et al. 1984, Randall et al. 1990) that settles exclusively into live coral (Eckert 1985).

The degree to which coral-dwellers and feeders are dependent upon live coral substratum requires a detailed study of ontogenetic changes in coral species selectivity from settlement to adulthood, both as habitat and/or a food source. Few such studies have been carried out (but see Bouchon-Navaro 1986, Guzman \& Robertson 1989). Coupled with information on habitat dynamics, this will determine the magnitude of population responses to disturbance and the mechanisms and time-scales of recovery. It appears that fish abundance may be correlated with habitat characteristics at some scales and not at others, but correlations alone do not reveal the underlying mechanisms of the interactions between reef fish and their habitat.

Although there are a variety of fishes associated with dead coral surfaces and rubble that appear to respond positively to disturbance (e.g. carnivorous wrasses; Walsh 1983), to date there have been no studies examining the foraging responses of corallivores to different sorts of coral stress, disease or mechanical damage. The aims of this study were 3-fold: (1) examine the effect of coral cover on the local abundance of
Labrichthys unilineatus (at different scales of sampling), and describe quantitatively ontogenetic patterns of habitat and coral diet selection within habitats; (2) examine foraging patterns in relation to naturally disturbed and damaged coral substrata; (3) investigate experimental response to local scale pulses of mechanical disturbance to live coral.

\section{MATERIALS AND METHODS}

This study was undertaken at Lizard Island $\left(14^{\circ} 40^{\prime} \mathrm{S}, 145^{\circ} 27^{\prime} \mathrm{E}\right)$ on the northern Great Barrier Reef, between September 1992 and March 1993. The principal study site was located at North Reef which forms part of a discontinuous fringing reef on the semiexposed side of the island (Choat \& Bellwood 1985). Behavioural observations, experiments and most censuses were conducted at this site on reef flat and shallow reef slope habitats exhibiting a diversity of coral species. Further censuses were carried out in the same reef zones between North Reef and Granite Bluffs, over a distance of approximately $1 \mathrm{~km}$. Labrichthys unilineatus was common in this area and is typically so on mid shelf to outer barrier reefs (Randall et al. 1990). It has distinctive juvenile (immature female), mature female and male (derived from sex change) colour phases, providing readily identifiable ontogenetic stages in their development.

Relationship between the abundance of Labrichthys unilineatus and coral cover. Differences in territory size of the 3 sexes (Mcllwain unpubl. data) meant the association between the abundance of $L$. unilineatus and coral cover was examined at 3 different sampling scales:

(1) Small scale: 23 replicate $2 \times 2 \mathrm{~m}$ quadrats placed haphazardly within a $50 \times 50 \mathrm{~m}$ area of North Reef were each marked out with a weighted rope. The quadrats were observed for three $30 \mathrm{~min}$ intervals, and the number of times an individual of Labrichthys unilineatus passed through the quadrat was recorded. Local activity was assessed as the total number of passes in $90 \mathrm{~min}$. Hard coral cover was assessed by recording the substratum under the intersections of a grid with $20 \times 20 \mathrm{~cm}$ squares placed over the whole $4 \mathrm{~m}^{2}$ area (i.e. a total of 100 points).

(2) Intermediate scale: 24 replicate $10 \times 10 \mathrm{~m}$ quadrats were placed haphazardly within the whole North Reef area and marked out with a weighted rope. Quadrats were censused once a day over a $3 \mathrm{~d}$ period, by counting all Labrichthys unilineatus within the quadrat at the time of the census. Local density was assessed as the total number of fish observed for the 3 censuses. As in the previous case, hard coral cover was assessed using a grid, but this time with $1 \times 1 \mathrm{~m}$ squares. 
(3) Large scale: eighteen $50 \times 5 \mathrm{~m}$ belt transects were censused between Granite Bluff and North Reef. On completion of each fish census, estimates of scleractinian coral cover were made for each transect using the line-intercept method (Dodge et al. 1982).

Ontogenetic changes in habitat use, diet and feeding selectivity. Patterns in coral consumption by Labrichthys unilineatus were examined by direct observations of feeding on different coral species. A total of 60 fish ( 20 males, 20 females and 20 juveniles) were observed for $10 \mathrm{~min}$ each between 10:00 and 14:00 $\mathrm{h}$, during 10 consecutive days in late January and early February 1993. Individuals were chosen at random within the study area. There was no diver-related effect on feeding behaviour during the observation periods (measured from a distance of $1.5 \mathrm{~m}$ ). For each observation period the number of bites made on different coral colonies and species was recorded. A distinction was made between bites taken on damaged and undamaged coral tissue, as early observations suggested damaged tissues were the focus of feeding activity. Sources of damage included coral colonies and fragments undergoing partial mortality through disease (e.g. black-band and white-band disease), bleaching, fragmentation or interactions with other colonies. Coral colonies from which $L$. unilineatus fed displayed only partial mortality as a result of disease, enabling identification of the remaining portion of the colony.

Because of the different sized territories occupied by the sexes it was necessary to quantify coral cover at the appropriate scales. The availability of different coral species to an individual fish was determined by the coral cover within the habitat it occupied. Male fish occupied large territories (Mcllwain unpubl. data), therefore estimates of food availability (live coral cover) were measured using the line intercept method (Dodge et al. 1982). Twenty transects (20 m long) were placed randomly within the study area as a whole. The intercept distance of coral species were recorded using the same species and categories as the feeding observations.

Juveniles and females exhibited highly restricted movements and were associated with particular patches of coral within the study site. To measure their habitat use and the availability of different coral species, coral cover measurements were made from within the home ranges of randomly chosen individuals. Seven female Labrichthys unilineatus and 14 juveniles were followed for $1 \mathrm{~h}$, and the boundaries of their feeding areas marked. For females, the percentage cover of coral types was calculated from estimates of home range size and measurements of the size of all coral colonies from within this area. For juveniles, this was estimated from a single $1 \mathrm{~m}^{2}$ quadrat with a grid of 200 points centred on their home range.
Ivlev's electivity index (Ivlev 1961) was used to measure feeding selectivity, comparing the utilisation of food with respect to its availability. Ivlev's index is defined as:

$$
E_{i}=\left(r_{i}-p_{i}\right) /\left(r_{i}+p_{i}\right)
$$

where $r_{i}$ is the proportion of food type $i$ consumed and $p_{i}$ is the proportion of this food type that is available in the environment. The $E$ values range from -1.0 to +1.0 with values between 0 and +1.0 indicating preference and values between 0 and -1.0 indicating avoidance, with a value of 0 for food types consumed in proportion to their availability (no selection). Separate indices were calculated for males, females and juveniles, based on the different estimates of consumption and availability for each ontogenetic stage.

Ontogenetic changes in the selection of damaged corals. In order to examine whether Labrichthys unilineatus was actively selecting damaged coral, the proportion of bites taken on damaged coral was compared to the proportional availability of damaged coral naturally occurring at the study site. The quadrat with the grid of 200 points was used to assess the proportion of tissue damaged for the coral species important in the diet. Replicate $1 \mathrm{~m}^{2}$ quadrats with a grid of 200 points were placed over randomly selected individual coral colonies totalling 145 colonies of 8 species. The number of points which fell on damaged, bleached, diseased or dead tissue was then expressed as a percentage of the total number of points which covered the colony. Based on the estimates of coral availability for the $3 \mathrm{~L}$. unilineatus ontogenetic categories, the percentage cover of damaged and undamaged coral available was then calculated.

Response of Labrichthys unilineatus to a small-scale experimental disturbance. Coral colonies were damaged experimentally to examine the effects of disturbance on the feeding behaviour of adult $L$. unilineatus. The experiment was carried out at North Reef over a period of 7 d during January and February 1993. Twelve replicate $1 \mathrm{~m}^{2}$ quadrats were haphazardly placed in the study site with an average of $20 \mathrm{~m}$ between quadrats. On Day 1 of the experiment the number of bites taken by all adults passing through the 12 quadrats on live coral and naturally damaged coral within the quadrats were recorded for 20 mins. On Day 2, 6 quadrats were selected at random and onethird of the coral within the quadrats was damaged by breaking off coral fragments using a hammer. The species of coral damaged and the amount of damage done was recorded. This disturbance was repeated within the same quadrats on Day 5

Following the disturbance, the bites on artificially damaged coral were recorded in addition to bites on undamaged and naturally damaged coral inside the 
quadrats for the same time period. The remaining 6 quadrats were undamaged and represent controls for the damage treatment. Observations of feeding behaviour at each of the 12 quadrats was randomised between 08:30 and 16:00 h. A repeated measures analysis of variance (Pillai's Trace) was used to test whether disturbance had any effect on the bite rate of Labrichthys unilineatus within the $1 \mathrm{~m}^{2}$ quadrats.

\section{RESULTS}

\section{Labrichthys unilineatus and its association with live coral}

The abundance of Labrichthys unilineatus was predicted by the amount of live coral cover, a pattern that was robust to differences in the scale of sampling (Fig. 1). The relationship between fish abundance and live coral displayed a significant linear or (slightly) curvi-linear trend, although the proportion of variance in abundance of fish explained declined with the increase in scale of sampling. At the $2 \times 2 \mathrm{~m}$ scale, coral cover explained $75 \%$ of the variation in use of quadrats by $L$. unilineatus. At the $50 \times 5 \mathrm{~m}$ scale, coral cover explained $45 \%$ of the variation in abundance.

\section{Ontogenetic changes in habitat use, diet and feeding preference}

There was a notable difference in the coral diets of males, females and juveniles (Fig. 2). Male Labrichthys unilineatus fed exclusively on species belonging to the family Acroporidae, especially Montipora spp. and Acropora hyacinthus. Females fed principally on the $A$. elseyi and $A$. nobilis, but also consumed $A$. hyacinthus and $A$. nasuta. Approximately $35 \%$ of the total bites by juveniles were taken on species belonging to the family Pocilloporidae, including Pocillopora damicornis and Stylophora spp. Like females, juveniles also fed on $A$. elseyi. One of the few species consumed by both juveniles and adults was $A$. nasuta. At no stage during the feeding observations were $L$. unilineatus seen to feed on anything other than coral. An examination of tissue sections of the hindgut of 15 individuals revealed that $85 \%$ contained the unexploded nematocysts of coral tissue (Mcllwain 1993). The presence of these nematocysts in the hindgut supports the behavioural observations that $L$. unilineatus appears to feed primarily on coral polyps.

The species composition of corals in the diet of males reflected their overall availability in the habitat, which was dominated by Montipora spp., Acropora hyacinthus and $A$. aculeus (Fig. 2). In contrast, $A$. elseyi and
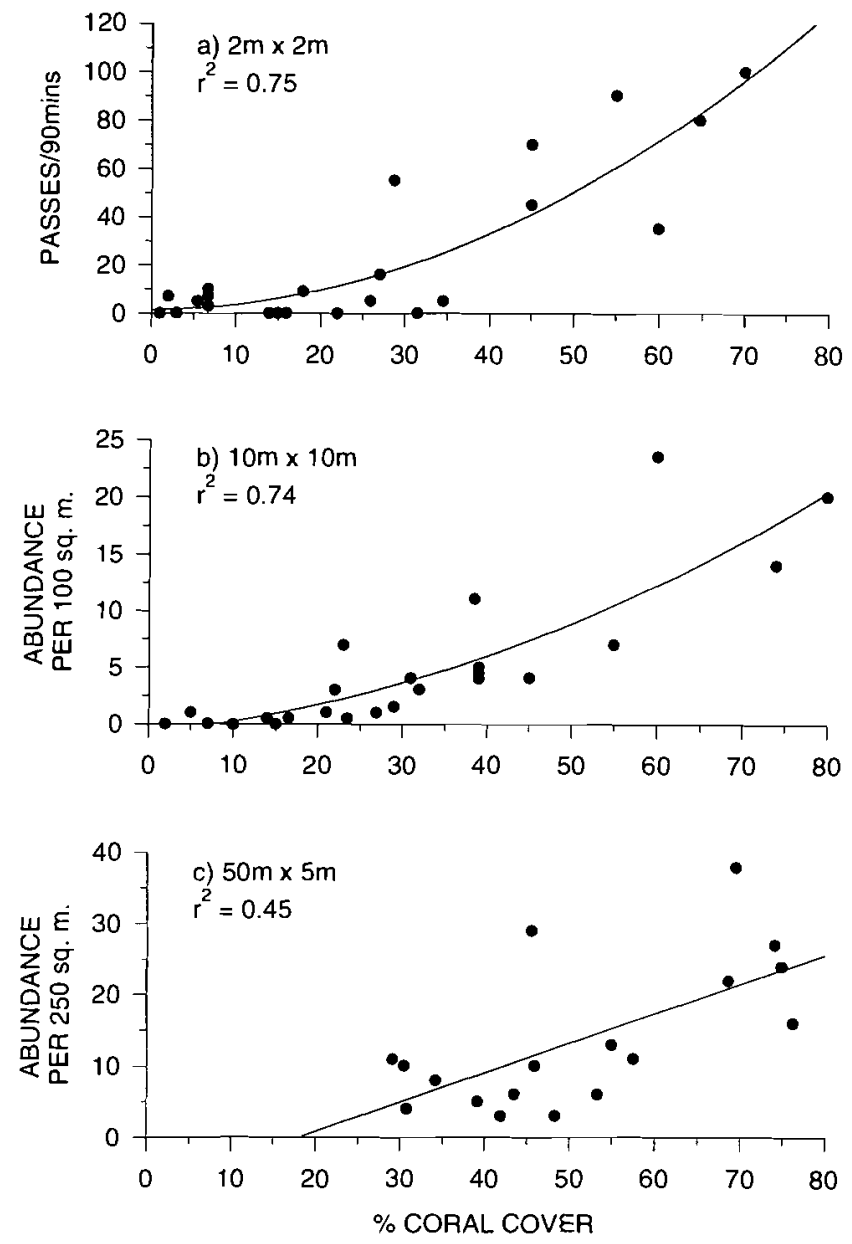

Fig. 1. Labrichthys unilineatus. Relationship between the estimates of local density of wrasse and the percent live hard coral cover at 3 different scales of sampling. (a) $2 \times 2$ m quadrats. Local density is estimated as total number of times individuals of L. unilineatus passed through a quadrat in $90 \mathrm{~min}$ of observations. $y=1.49+0.035 x+0.019 x^{2}, n=23$. (b) $10 \times 10 \mathrm{~m}$ quadrats. Local density is estimated as total of 3 replicate censuses over a 3 d period. $y=-0.672+0.07 x+2.407 x^{2}, n=24$. (c) $50 \times 5 \mathrm{~m}$ transect. Local estimate based on single census of each transect. $y=-7.45+0.414 x, \mathrm{n}=18$. Regression lines are shown where there is a significant relationship

A. nobilis were the most abundant corals in the feeding territories of the females. These 2 coral species were also the most common corals in the diet of female Labrichthys unilineatus, indicating non-random distribution of females within the study site. Their diet appeared to at least partially reflect this difference in availability of corals within their home ranges. Although the juveniles had the most species of coral available in their territories, only 2 species, A. elseyi and $A$. nobilis, were abundant. While these species were consumed, they did not make up the majority of the coral in the diet of juveniles. Lesser abundant coral species such as Pocillopora damicornis, Stylophora 

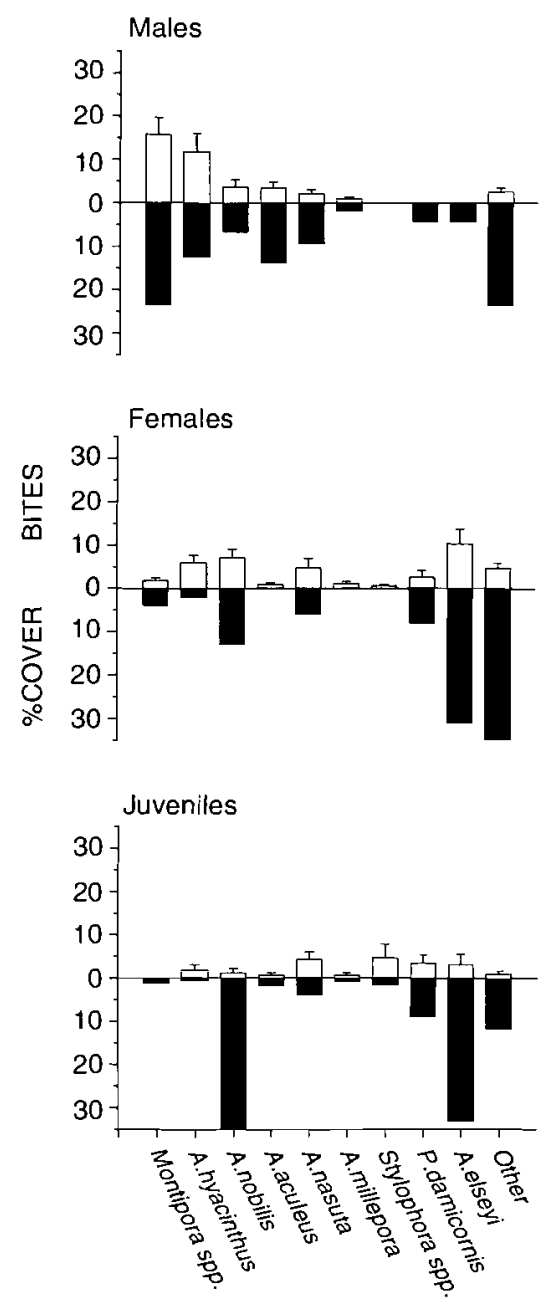

Fig. 2. Labrichthys unilineatus. Mean $( \pm \mathrm{SE})$ number of bites (damaged and undamaged pooled; open bars) on 9 coral taxa by male, female and juvenile wrasse during a $10 \mathrm{~min}$ time period, with the remaining bites pooled as the other category. Closed bars represent the mean \% cover of these corals within the home ranges of each of the sexes $(n=60)$

spp. and $A$. nasuta made up a substantial component of the diet of juveniles.

Patterns of feeding selectivity also had an influence on diets (Fig. 3). While males consumed many common species almost in proportion to their availability (Montipora spp. and Acropora hyacinthus), they also omitted certain species from their diet, including $A$. elseyi, Pocillopora damicornis and Stylophora spp. Females appeared to select a number of rare species in their home ranges including $A$. aculeus and Stylophora spp., while at the same time consuming common species almost in proportion to their availability (e.g. Montipora spp. and A. nobilis). Juveniles were the most selective in their feeding, preferentially consuming a number of coral species that were rare within their home ranges (e.g. A. millepora and Stylophora spp.) and avoiding
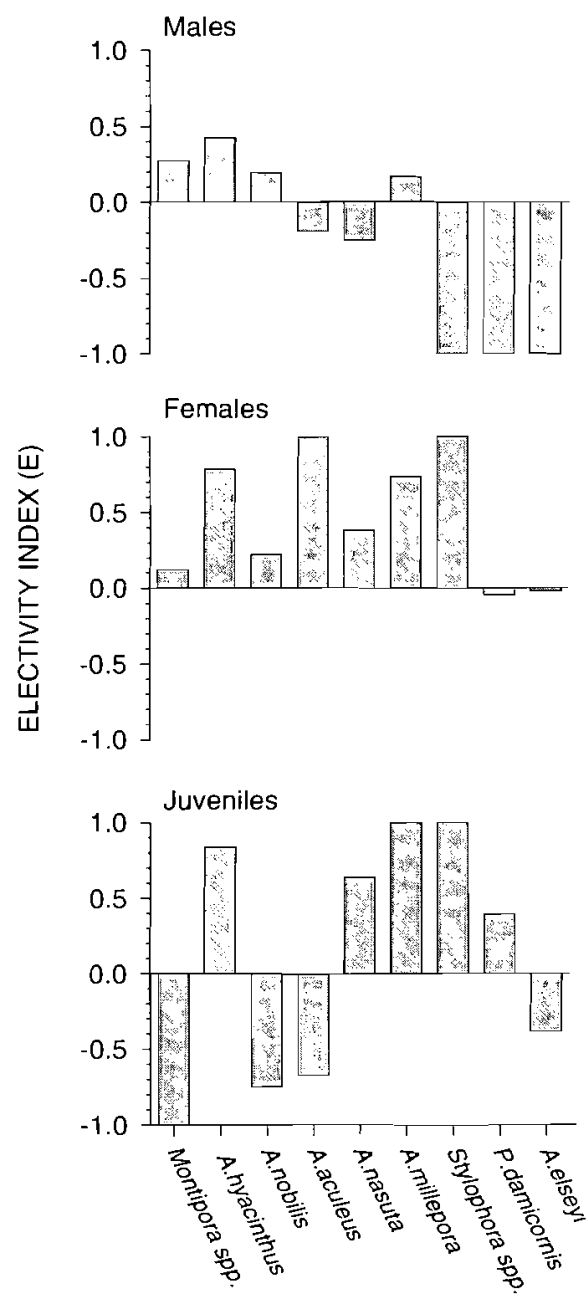

Fig. 3. Labrichthys unilineatus. Selectivity of consumption of different coral species by male, female and juvenile wrasse using Ivlev's electivity index. $E$ values range from 1 (strongly selected) to -1 (strongly avoided), with a value of 0 for food types consumed in proportion to their availability (no selection) $(n=60)$

the most common species ( $A$. elseyi and $A$. nobilis). Unlike males and juveniles, the female fish did not show any species avoidance, evident by the lack of coral species with larger values in the 0 to -1 range.

\section{Importance of naturally occurring damaged coral in the diet of Labrichthys unilineatus}

There was a strong ontogenetic change in the importance of damaged coral in the diet of Labrichthys unilineatus (Fig. 4, Table 1). The ratio of mean bites on damaged and undamaged coral was highest (53\%) for males with females and juveniles taking $15 \%$ and $5 \%$ of their total bites from damaged coral respectively. In contrast, the mean bites on undamaged coral tissues 


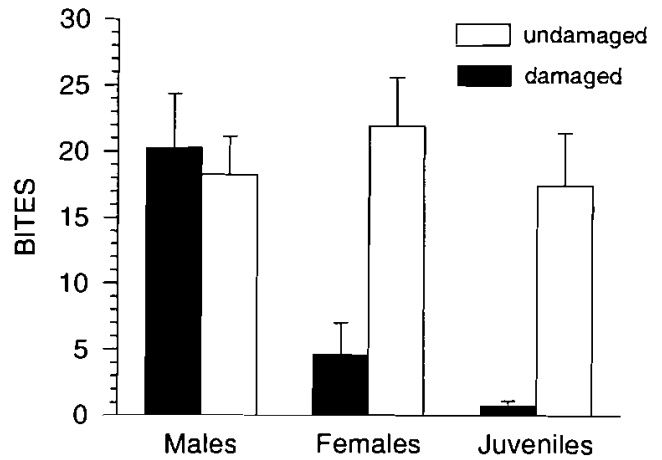

Fig. 4. Labrichthys unilineatus. Summary of the split plot ANOVA of bites on damaged and undamaged corals by 20 of each of male, female and juvenile wrasse. Each bar represents the backtransformed mean $+\mathrm{SE}(n=60)$. Bite rate refers to the number of bites per $10 \mathrm{~min}$

were relatively similar for the 3 ontogenetic stages, the source of the highly significant interaction between 'sex' and 'bites' in the ANOVA (Table 1).

All ontogenetic stages were selecting damaged coral tissues, the greater consumption by males reflecting a greater availability. Over half the number of bites taken by male Labrichthys unilineatus were on damaged coral, even though this made up less than $5 \%$ of the live coral substratum within their territories (Fig. 5). Females utilised one-quarter of their feeding activity biting damaged coral tissue, but these tissues accounted for only $2.5 \%$ of the total coral cover. Damaged coral made up approximately $5 \%$ of the diet of juveniles, but represented less than $0.5 \%$ of the total coral cover available to them.

There was also a strong ontogenetic change in the coral species from which damaged tissues were being consumed (Fig. 5). Males consumed mainly damaged Montipora spp., females consumed almost entirely damaged Acropora elseyi, and damaged A. nobilis dominated the diet of juveniles. In each case, the dominant coral species from which damaged tissue was

Table 1. Labrichthys unilineatus. Summary of the results of the split plot ANOVA on the number of bites taken on undamaged and damaged coral tissue by male, female and juvenile wrasse. Analysis was performed on $\ln (x+1)$ transformed data

\begin{tabular}{|lrrrc|}
\hline Source & df & MS & $F$ & $p$ \\
\hline $\begin{array}{lrrr}\text { (1) Among sexes } \\
\text { Sex (S) }\end{array}$ & 2 & 16.512 & 27.794 & $<0.0001$ \\
Residual & 57 & & & \\
(2) Within sexes & & & & \\
Bites (B) & 1. & 45.411 & 56.938 & 0.0001 \\
$\begin{array}{l}\text { S B B } \\
\text { Residual }\end{array}$ & 2 & 15.591 & 19.548 & 0.0001 \\
& 57 & 0.798 & & \\
\hline
\end{tabular}

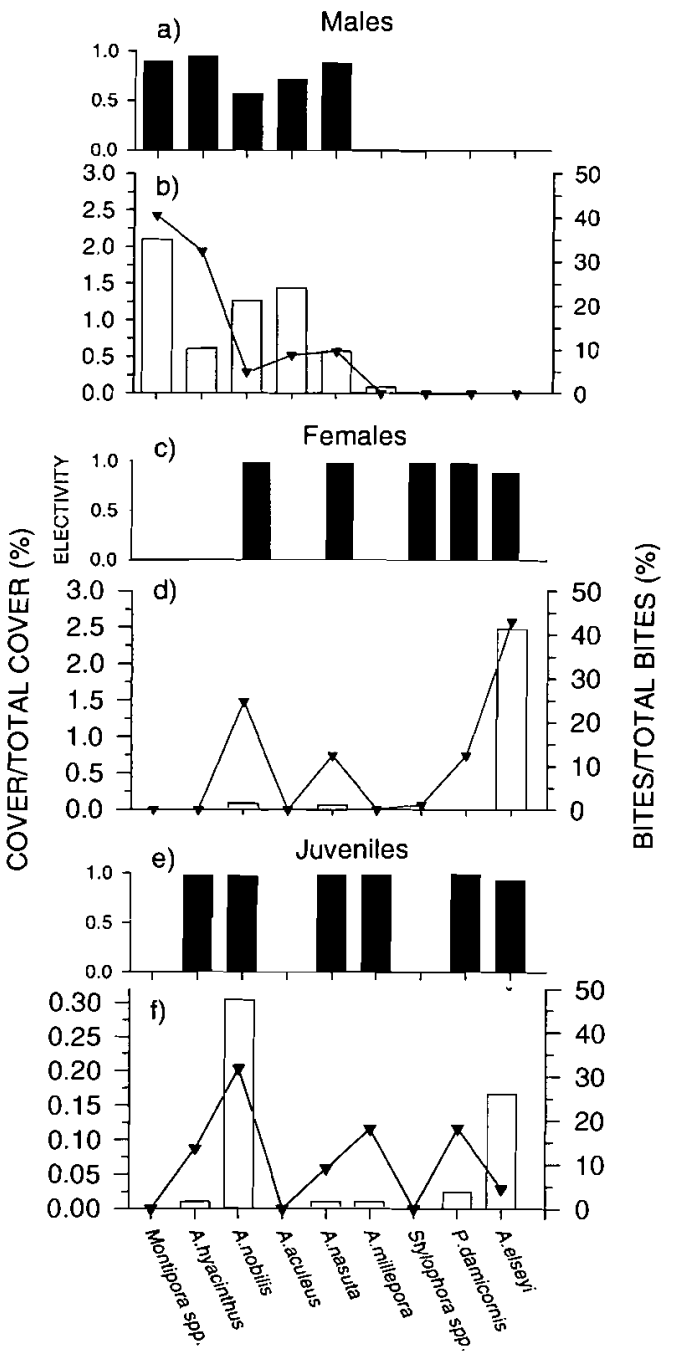

Fig. 5. Labrichthys unilineatus. Percentage of the total number of feeding bites by (b) male, (d) female and (f) juvenile wrasse on damaged coral of different coral species (lines), and the proportional cover of damaged coral tissue within the home ranges (bars). Note the $y$-axis of the juvenile graph has a different scale. $(a, c$, e) Measurements of the electivity index for each of the sexes. See Fig. 3 for an explanation of the axis. Note that no damaged coral was avoided, hence the absence of values ranging from 0 to -1

eaten corresponded with the coral species which provided the greatest availability of damaged tissue. However, when the remaining coral species were considered there was little concordance between the proportion of feeding bites taken from damaged tissue of different corals and the availability of damaged tissue. Hence, all stages including males, females and juveniles 'were selective among coral species when consuming damaged tissues. In addition the electivity index showed a high degree of selection when damaged coral tissue was present in feeding territories with no sign of avoidance by any of the sexes (Fig. 5). 


\section{Response of Labrichthys unilineatus to a small-scale experimental disturbance}

Disturbance of the habitat of adult Labrichthys unilineatus had a dramatic effect on the total number of bites taken on coral within a given area (Fig. 6). The total bites taken by adult fish on coral differed between days and between the treatment and control quadrats as described by the repeated measures analysis (Table 2). On Days 2 and 5 of the experiment when disturbance of the treatment quadrats occurred, feeding within these quadrats increased 13 - and 7 -fold respectively. The effect of the disturbance was short term as the feeding frequency on Day 3 returned to a predisturbed level. This supports the results of the natural

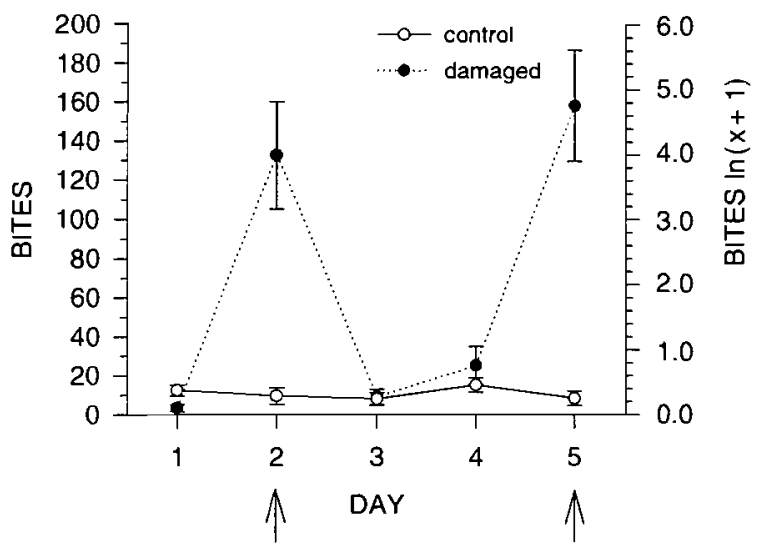

Fig. 6. Labrichthys unilineatus. Change in the number of bites taken in experimentally disturbed $1 \mathrm{~m}^{2}$ quadrats (dotted line) and control quadrats (continuous line) during a $5 \mathrm{~d}$ period. Each point is the mean \pm SE of 6 quadrats, plotted as the $\ln (x+1)$ transformation (right hand scale) and the back transformed data shown on the left hand scale. Arrows denote days when mechanical disturbances to the corals within each treatment quadrat took place

Table 2. Labrichthys unilineatus. Summary of the results of the repeated measures ANOVA of the number of bites taken in experimentally disturbed $1 \mathrm{~m}^{2}$ plots during a $5 \mathrm{~d}$ period.

Analysis was performed on $\ln (x+1)$ transformed data

\begin{tabular}{|c|c|c|c|c|}
\hline $\begin{array}{l}\text { (1) Among qua } \\
\text { Source }\end{array}$ & $\begin{array}{l}\text { ats } \\
\text { df }\end{array}$ & MS & $F$ & $\mathrm{p}$ \\
\hline Treatment (T) & 4 & 8.168 & 9.907 & 0.0001 \\
\hline Residual & 10 & 2.903 & & \\
\hline \multicolumn{5}{|c|}{ (2) Within quadrats } \\
\hline Source & df & Pillai Trace & $F$ & $\mathrm{p}$ \\
\hline Day (D) & 4,7 & 0.880 & 12.801 & 0.0025 \\
\hline $\mathrm{T} \times \mathrm{D}$ & 4,7 & 0.919 & 19.977 & 0.0006 \\
\hline
\end{tabular}

feeding study which revealed that $L$. unilineatus showed a strong preference for the damaged tissue of coral polyps.

\section{DISCUSSION}

The abundance of the Labrichthys unilineatus was high in areas with greater cover of hard corals, the latter explaining between 45 and $75 \%$ of the variation in fish densities. This is a fairly typical pattern for corallivorous species, particularly among the more widely studied butterflyfish (Chaetodontidae) (e.g. Bell \& Galzin 1984, Bell et al. 1985, Bouchon-Navaro \& Bouchon 1989). The strength of the correlation varies, with many studies also recording little or no effect of the substratum on abundance (Fowler 1990, Cox 1994). Such differences and apparently conflicting patterns are frequently put down to differences in the scale of sampling employed (Roberts \& Ormond 1987). In this case the correlation was robust, being detected at 3 different scales of sampling. The results suggest that disturbances at all these scales which reduce coral cover could have a negative effect on the abundance of this wrasse.

Loss of live coral cover might be expected to affect Labrichthys unilineatus populations, as observations of feeding behaviour showed that individuals were dependent on live coral for food. However, subdivision of the wrasse into different ontogenetic stages and scleractininan corals into component species exposes a more complex picture. There were clear differences among males, females and juveniles in every aspect of feeding behaviour, including diet and degree of prey selectivity. Since $L$. unilineatus is a protogynous hermaphrodite, these differences are likely to reflect ontogenetic patterns that are linked to growth, changing ecological requirements and reproductive aspects of their development.

Ontogenetic changes in diet reflected both changes in the availability of corals to juveniles, females and males, and changes in feeding selectivity. Juveniles exhibited strong habitat selection within the study area, being closely associated with gullies containing large patches of Acropora nobilis, A. elseyi and Pocillopora damicornis. This placed a restriction on the range of coral types available to them. However, within these areas they fed on certain coral species, preferentially consuming A. millepora, Stylophora spp. and A. hyacinthus.

Males roamed far more widely throughout the study area than juveniles and consequently had a greater range of coral types available to them. They exhibited a completely different diet, dominated by Montipora spp. and Acropora hyacinthus. Since these corals were 
also those that dominated in the habitat, the species composition in the diet of males more closely matched their availability in the field, although certain species present were clearly being avoided. Females were intermediate in size and habit, being slightly less associated with patches of $A$. nobilis and $A$. elseyi than juveniles and selecting a wider range of coral species, including those consumed by males.

This ontogenetic shift in diet toward acroporid species may be a result of a gradual release in predation pressure, as adults can presumably forage further from shelter (Jones 1984, Ebeling \& Laur 1985). As well as providing food, the finely branched forms consumed by juveniles probably act as effective refuges from predators. For example, Jones (1988) found the survivorship of juveniles of 2 species of pomacentrid to increase on patch reefs constructed of Pocillopora damicornis, compared with less densely branched species.

Patterns of feeding selectivity for different coral species may relate to preferences based on the nutritional status of the food or morphological characteristics. Coral tissue with a high caloric value may be strongly selected by Labrichthys unilineatus. Tricas (1985) found Chaetodon multicinctus showed strong selection for Pocillopora meandrina when transplanted into their feeding territories. $P$. meandrina had a higher energy content in comparison with Porites lobata and Porites compressa that occurred naturally in the study site. Similarly the selection of coral by individuals may correspond with the shape of the corallite or the distance between the polyps. Corallites that are knob-like in appearance (like acroporids) may allow easier access to the polyp tissue compared with polyps which are protected by meandroid, plocoid or cerioid shaped corallites (Reese 1977). Corals which display these corallite shapes such as faviids and fungiids were avoided by $L$. unilineatus of all sizes. Neudecker (1985) found that $C$. capistratus avoided corals belonging to the Mussidae, Meandrinidae, and Faviidae families. However, he suggested that this may be a result of the development of biochemical defences by these coral species against predators rather than the shape of the corallite.

The observed patterns of diet and feeding preference became even more complex when damaged and undamaged corals were distinguished. Adult Labrichthys unilineatus, which were less selective than juveniles in terms of coral species consumed, selected damaged coral tissue as a food source. Bleaching, fragmentation and disease (e.g. black-band and whiteband disease) were the typical causes of natural damage at the study site. The ontogenetic change in the consumption of damaged and diseased coral tissue by L. unilineatus was dramatic. Damaged tissue comprised half of the total number of bites taken by males, approximately one quarter of the bites by females and a relatively trivial component of the diet of juveniles.

Again, this change in consumption partially reflected changes in availability and preference toward damaged tissues. The restriction of juveniles to patches of live coral may have reduced the availability of damaged coral tissues. Of those available, they tended to consume the species with the greatest percentage damage. The larger home range and greater mobility displayed by males and their defence of feeding territories may allow them greater access to damaged coral colonies.

Olfactory attractants released by naturally damaged coral tissue may be responsible for the selection of damaged and diseased coral tissue. There may be no particular advantage to consuming damaged tissue, due either to a reduction in feeding deterrents or increased energy rewards, but simply an increase in the waterborne stimuli that attract individuals to feeding sites. Unfortunately limited data are available on the chemical compounds released by coral undergoing disease or damage. More detailed diet and food selection experiments will be necessary to distinguish among these possibilities.

The selection by a corallivore on damaged coral tissues has not been previously recorded. It is apparent from the manipulative experiment that Labrichthys unilineatus responds to localised disturbances, which become the focus of increased feeding activity. Localised disturbances may have a greater effect on local distributions than the structure of the habitat itself. Individuals feeding in damaged areas clearly have the possibility of increased food intake.

The impact of physical disturbance to habitat on Labrichthys unilineatus is likely to be influenced by its scale and intensity. Individuals clearly respond to and may benefit from small-scale, low intensity disturbances. It appears that they may be adapted to take advantage of the normal, 'background' level of disturbance on the reef. On the other hand, the amount of recently damaged coral tissue available to the population will increase with overall coral cover. If the damage created by a physical or biological disturbance event is severe and results in a dramatic loss of live coral then the population of corallivores is also likely to decline. Similarly, the wrasse may differ in its shortterm and long-term response to elevated disturbance. The initial effect may be positive, as individuals select damaged and diseased coral tissue during the early stages. However, the long-term effect at the level of the population may be a decline. Further manipulative experiments are required to determine whether other species of corallivores such as butterflyfish show a similar positive response to natural damage and smallscale disturbances. 
Acknowledgements. Special thanks to Uschi Kaly for her invaluable help in the field and discussion in the early stages of the project. Thanks also to R. Black, M. McCormick and C. Syms who assisted in the preparation of the manuscript, and M. Marnane who acted as volunteer dive buddy. This research was funded partially by a Great Barrier Reef Marine Park Authority Augmentative grant (J.L.MCI.) and undertaken at the Australian Museum Lizard Island Research Station. The manuscript was prepared whilst J.L.McI. was the holder of an Australian Institute of Marine Science post-graduate scholarship undertaken at the Dept of Zoology, University of Western Australia (UWA) and benefited from the comments of the Marine Ecology discussion group (UWA).

\section{LITERATURE CITED}

Bell JD, Galzin R (1984) Influence of live coral cover on coral reef fish communities. Mar Ecol Prog Ser 15:265-274

Bell JD, Harmelin-Vivien ML, Galzin R (1985) Large scale spatial variation in abundance of butterflyfishes (Chaetodontidae) on Polynesian reefs. Proc 5th Int Coral Reefs Symp Congr 5:421-426

Bouchon-Navaro Y (1986) Partitioning of food and space resources by chaetodontid fishes on coral reefs. J Exp Mar Biol Ecol 103:21-40

Bouchon-Navaro Y, Bouchon C (1989) Correlations between chaetodontid fishes and coral communities of the Gulf of Aqaba (Red Sea). Environ Biol Fish 25:47-60

Bouchon-Navaro Y, Bouchon C, Harmelin-Vivien ML (1985) Impact of coral degredation on a chaetodontid fish assemblage (Moorea, French Polynesia). Proc 5th Int Coral Reefs Symp Congr 5:427-432

Carpenter KE, Miclat RI, Albaladejo VD, Corpuz VT (1981) The influence of substrate structure on the local abundance and diversity of Philippine reef fishes. Proc 4th Int Coral Reef Symp 2:497-502

Choat JH, Bellwood DR (1985) Interactions amongst herbivorous fishes on a coral reef: influence of spatial variation. Mar Biol 89:221-234

Connell JH (1978) Diversity in tropical rain forests and coral reefs. Science 199:1302-1310

Cox EF (1994) Resource use by corallivorous butterflyfishes (family Chaetondontidae) in Hawaii. Bull Mar Sci 54: $535-545$

Dawson-Shepherd AR, Warwick RM, Clarke KR, Brown BE (1992) An analysis of fish community responses to coral mining in the Maldives. Environ Biol Fish 33:367-380

Dodge RE, Logan AL, Antonius A (1982) Quantitative reef assessment studies in Bermuda: a comparison of methods and preliminary results. Bull Mar Sci 32:745-760

Ebeling AW, Laur DR (1985) The influence of plant cover on surfperch abundance at an offshore temperate reef. Environ Biol Fish 12:169-179.

Eckert GJ (1985) Settlement of coral reef fishes to different natural substrata and at different depths. Proc 5th Int Coral Reefs Symp Congr 5:385-390

Fowler AJ (1990) Spatial and temporal patterns of distribution and abundance of chaetodontid fishes at One Tree Reef, southern GBR. Mar Ecol Prog Ser 64:39-53

Gladfelter WB, Gladfelter EH (1978) Fish community structure as a function of habitat structure on West Indian patch reefs. Rev Biol Trop 26:65-84

Guzman HM, Robertson DR (1989) Population and feeding responses of the corallivorous pufferfish Arothron meleagris to coral mortality in the eastern Pacific. Mar Ecol Prog Ser 55:121-131
Harmelin-Vivien ML, Laboute P (1986) Catastrophic impact of hurricanes on atoll outer reef slopes in the Tuamotu (French Polynesia). Coral Reefs 5:55-62

Hoffman SG (1983) Sex-related foraging behaviour in sequentially hermaphroditic hogfishes (Bodianus spp.). Ecology 64:798-808

Hourigan TF, Tricas TC, Reese ES (1988) Coral reef fishes as indicators of environmental stress in coral reefs. In: Soule DF, Kleppel J (eds) Marine organisms as indicators. Springer-Verlag, New York, p 107-136

Hughes TP, Reed DC, Boyle MJ (1987) Herbivory on coral reefs: community structure following mass mortalities of sea urchins. J Exp Mar Biol Ecol 113:39-59

Ivlev VS (1961) Experimental ecology of the feeding of fishes. Yale University Press, New Haven

Jackson JBC (1991) Adaptation and diversity of reef corals. BioSci 41:475-482

Jones GP (1984) The influence of habitat and behavioural interactions on the local distribution of the wrasse, Pseudolabrus celidotus. Environ Biol Fish 10:43-58

Jones GP (1988) Experimental evaluation of the effects of habitat structure and competitive interactions on the juveniles of two coral reef fishes. J Exp Mar Biol Ecol 123: $115-126$

Jones GP, Kaly UL (1995) Criteria for selecting marine organisms in biomonitoring studies. In: Schmitt RJ, Osenberg CW (eds) Detection of ecological impacts: conceptual issues and application in coastal marine habitats. Academic Press, New York, p 29-48

Kaufman LS (1983) Effects of Hurricane Allen on reef fish assemblages near Discovery Bay, Jamaica. Coral Reefs 2: 43-47

Krupp DA (1984) Mucus production by corals exposed during an extreme low tide. Pac Sci 38:1-11

Lassig BR (1983) The effects of a cyclonic storm on a coral reef fish assemblages. Environ Biol Fish 9:55-63

Levin PS (1991) Effects of microhabitat on recruitment variation in a Gulf of Maine reef fish. Mar Ecol Prog Ser 75: 183-189

Luckhurst BE, Luckhurst K (1978) Analysis of the influence of substrate variables on coral reef fish communities. Mar Biol 49:317-323

McIlwain JL (1993) The effect of habitat structure and disturbance on the ecology of a coral-feeding fish Labrichthys unilineatus (Labridae). Honours thesis, James Cook University, Townsville

Neudecker S (1985) Foraging patterns of Chaetodontid and Pomacanthid fishes at St. Croix (U.S. Virgin Islands). Proc 5th Int Coral Reefs Symp Congr 5:415-420

Pearson RG (1981) Recovery and recolonization of coral reefs. Mar Ecol Prog Ser 4:105-122

Pfeffer RA, Tribble GW (1985) Hurricane effects on an aquarium fish fishery in the Hawaiian Islands. Proc 5th Int Coral Reefs Symp Congr 3:331-336

Randall JE, Allen GR, Steene RC (1990) Fishes of the Great Barrier Reef and the Coral Sea. Crawford House Press, Bathurst

Reese EJ (1977) Coevolution of corals and coral feeding fishes of the Family Chaetodontidae. Proc 3rd Int Coral Reefs Symp 2:267-274

Roberts CM, Ormond RFG (1987) Habitat complexity and coral reef fish diversity and abundance on Red Sea fringing reefs. Mar Ecol Prog Ser 41:1-8

Sano M, Shimizu M, Nose Y (1984) Changes in structure of coral reef fish communities by destruction of hermatypic corals: observational and experimental views. Pac Sci 38: $51-79$ 
Sano M, Shimizu M, Nose Y (1987) Long-term effects of destruction of hermatypic corals by Acanthaster planci. Mar Ecol Prog Ser 37:191-199

Tricas TC (1985) The economics of foraging in coral-feeding butterflyfishes of Hawaii. Proc 5th lnt Coral Reefs Symp Congr 5:409-414

Walsh WJ (1983) Stability of a coral reef fish community following a catastrophic storm. Coral Reefs 2:49-63

Wellington GM, Victor BC (1985) El Niño mass coral mortality: a test of resource limitation in a coral reef damselfish population. Oecologia 68:15-19

Williams AH (1984) The effects of Hurricane Allen on back

This article was presented by Daniel Alongi (Senior Editorial Advisor), Townsville, Queensland, Australia reef populations of Discovery Bay, Jamaica. J Exp Mar Biol Ecol 75:233-243

Williams DMcB (1986) Temporal variation in the structure of reef slope fish communities (central Great Barrier Reef): short-term effects of Acanthaster planci infestation. Mar Ecol Prog Ser 28:157-164

Woodley JD, Chornesky EA, Clifford PA, Jackson JBC, Kaufman LS, Knowlton N, Lang JC, Pearson P, Porter JW, Rooney MC, Rylaarsdam KW, Tunnicliffe VJ, Wahle CM, Wulff JL, Curtis ASG, Dallmeyer MD, Jupp BP, Koehl MAR, Neigel J, Sides EM (1981) Hurricane Allen's impact on Jamaican coral reefs. Science 214:749-755

Manuscript received: November 9, 1996

Revised version accepted: May 9, 1997 